\title{
a expansão das fronteiras econômicas dos estados unidos: o "anticolonialismo imperial" e a disputa pelo mercado chinês na interpretação historiográfica revisionista*
}

\section{the expansion of the economic frontiers of the united states: the "imperial anticolonialism" and the struggle for the chinese market in the revisionist historiographical interpretation}

\author{
Flávio Alves Combat ${ }^{\star} \star$ \\ Instituto de Relações Internacionais e Defesa, Universidade Federal do Rio de Janeiro, Rio de Ja- \\ neiro, Rio de Janeiro, Brasil
}

\begin{abstract}
Resumo
O objetivo do artigo é analisar a interpretação da corrente historiográfica revisionista sobre as transformações na política externa conduzida pelos Estados Unidos, na virada do século XIX para o século XX (1890-1909). O texto retoma a análise desenvolvida pelos historiadores revisionistas William Appleman Williams e Walter LaFeber sobre o "anticolonialismo imperial" engendrado pelos Estados Unidos no processo de disputa pela abertura do mercado chinês. $O$ trabalho defende que a política externa norte-americana radicada nos princípios da Open Door Policy está na origem dos conflitos com as tradicionais potências imperialistas que competiam pelo controle e pela influência sobre as prósperas fronteiras econômicas da China.
\end{abstract}

Palavras-chave: Revisionismo. Anticolonialismo. Open Door Policy. Política externa norte-americana. China.

\begin{abstract}
The purpose of this article is to analyze the interpretation of the revisionist historiographical strand on the transformations in the foreign policy conducted by the United States at the turn of the 19th century to the 20th century (1890-1909). The paper retakes the analysis developed by the revisionist historians William Appleman Williams and Walter LaFeber on the "imperial anticolonialism" engendered by the United States in the process of dispute for the opening of the Chinese market. It's argued that that US foreign policy rooted in the principles of Open Door Policy is at the origin of the conflicts with traditional imperialist powers competing for control and influence over China's thriving economic frontiers.
\end{abstract}

Keywords: Revisionism. Anticolonialism. Open Door Policy. US foreign policy. China.

\footnotetext{
* Submetido: 26 de setembro de 2017; aceito: 28 de junho de 2018.

$\star \star$ Professor adjunto do Instituto de Relações Internacionais e Defesa da Universidade Federal do Rio de Janeiro. Doutor em História Comparada pela Universidade Federal do Rio de Janeiro. E-mail: facombat@gmail.com
} 


\section{Introdução}

O revisionismo, principal corrente historiográfica que questionou as teses da ortodoxia, é frequentemente empregado para entender o período de aprofundamento das tensões entre os Estados Unidos e a União Soviética após a Segunda Guerra Mundial. Contudo, as contribuições revisionistas não se limitaram ao período da Guerra Fria. De fato, William Appleman Williams (o "pai" do revisionismo), em seu clássico The tragedy of American diplomacy (1959), e Walter LaFeber (discípulo de Williams), em The American age (1989), defenderam que os conflitos que deram início à rivalidade entre a Rússia e os Estados Unidos foram iniciados já no século XIX, em torno da pressão pela abertura da Ásia ao capital e à influência política norte-americanos.

Ao analisar as transformações da política externa norte-americana, entre o final do século XIX e as primeiras décadas do século XX,Williams e LaFeber concluíram que os Estados Unidos colocaram em curso uma política de "anticolonialismo imperial": ao combater, inclusive militarmente, as políticas colonialistas das tradicionais potências imperialistas que disputavam os mercados asiáticos (em especial, o próspero mercado chinês), os Estados Unidos defendiam os seus próprios interesses expansionistas imperiais.

O revisionismo sustentou, nesse sentido, a tese de que a introjeção dos princípios da Open Door Policy na política externa estadunidense fomentou um conjunto de contradições e antagonismos que contribuíram para o surgimento e aprofundamento de tensões entre os Estados Unidos e as antigas potências imperialistas - identificando, nesse processo histórico, a origem de tendências que contribuíram inclusive para a Guerra Fria.

O objetivo do artigo é analisar a interpretação da corrente historiográfica revisionista sobre as transformações na política externa conduzida pelos Estados Unidos, na virada do século XIX para o século XX (da década de 1890 até 1909). Na primeira seção, analiso o contexto histórico e as principais ideias do debate historiográfico entre a ortodoxia, o revisionismo e o pós-revisionismo, de modo a contextualizar as ideias dos dois autores revisionistas que fundamentam o artigo. $\mathrm{Na}$ segunda seção, analiso a origem, as motivações e as primeiras consequências do "anticolonialismo imperial", a partir da interpretação 
proposta por Williams. Na terceira seção, proponho uma articulação entre a análise originalmente desenvolvida porWilliams e a interpretação de LaFeber sobre os conflitos gestados pela política externa expansionista conduzida pelos Estados Unidos para conquistar as fronteiras econômicas chinesas.

\section{O debate historiográfico entre a ortodoxia, 0 revisionismo e o pós-revisionismo}

O debate sobre a política externa dos Estados Unidos e as suas relações com a Rússia e, posteriormente, com os países do bloco soviético foi protagonizado por três correntes historiográficas de grande projeção dentro e fora da Academia norte-americana: a ortodoxia, o revisionismo e o pós-revisionismo. Nesta seção, apresentarei uma síntese desse debate historiográfico, de forma a contextualizar historicamente as teses revisionistas analisadas mais detidamente ao longo do artigo.

Entre o fim da Segunda Guerra Mundial e o envolvimento norte-americano na Indochina, a corrente historiográfica ortodoxa explicou, de forma hegemônica, o significado da Guerra Fria e das relações entre os Estados Unidos e os países alinhados à URSS. As suas teses alcançaram grande projeção, dentro e fora dos Estados Unidos, e se tornaram a principal base de legitimação social da política externa conduzida pela Casa Branca na segunda metade do século XX. O principal representante da ortodoxia foi o diplomata norte-americano George Frost Kennan. As ideias de Kennan formaram o eixo teórico da política externa conduzida pela Casa Branca durante toda a Guerra Fria, sintetizado na "Doutrina de Contenção do Comunismo".

Kennan era um estudioso da União Soviética e compreendia as suas prioridades políticas e econômicas após a Segunda Guerra. Nesse sentido, a Doutrina de Contenção do Comunismo, longe de qualquer idealismo pacifista, explorava exatamente o diferencial de poder entre os Estados Unidos e a União Soviética após a Segunda Guerra, defendendo assim a "aplicação hábil e vigilante de contraforças em uma série de pontos geográficos e políticos em constante mudança” (Kennan, 1947, p. 5). O sucesso dessa doutrina deve ser analisado, portanto, à luz da perspicácia de seu formulador, que ofereceu à sociedade norte-americana 
uma explicação sobre a Guerra Fria que desonerava os Estados Unidos de qualquer responsabilidade sobre a escalada da tensão entre Washington e Moscou.

A responsabilização unilateral da União Soviética pela Guerra Fria é, segundo Munhoz (2004), o eixo central da interpretação ortodoxa. O projeto soviético, segundo os ortodoxos, não se limitava ao Leste Europeu. A presença da União Soviética na Alemanha seria um indício da intenção do líder soviético Josef Stalin de invadir a Europa Ocidental e, em seguida, disseminar o comunismo pelo mundo. Os Estados Unidos teriam sido forçados, nesse sentido, a assumir internacionalmente a liderança dos países capitalistas, respondendo ao expansionismo soviético com uma política externa voltada para a contenção do comunismo.

Na década de 1960, o envolvimento dos Estados Unidos na Guerra da Indochina aprofundou as críticas aos objetivos declarados pela Casa Branca com a política de contenção do comunismo. A corrente revisionista, principal abordagem crítica que contestou as teses da ortodoxia, ganhou projeção exatamente no contexto da intervenção norte-americana no Sudeste Asiático, que marcou um período de amplo questionamento do papel dos Estados Unidos na política internacional. Dentre os representantes do revisionismo norte-americano, destacam-se William Appleman Williams e Walter LaFeber.

A consolidação da corrente revisionista sobre a Guerra Fria coincidiu, nos Estados Unidos, com o auge da New Left, o amplo movimento político de esquerda, com repercussão em vários países, identificado, no caso norte-americano, com o movimento hippie, com os protestos pelos direitos civis e com as manifestações de oposição à Guerra do Vietnã. Como observado pelo historiador Daniel Smith, "ao final da década de 1950 e preponderantemente na década de 1960, uma New Left começou a emergir com a sua própria visão histórica sobre os recentes eventos mundiais" (Smith, 1970, p. 79). No campo da história dedicado ao estudo da Guerra Fria (comumente referido, no meio acadêmico estadunidense, como "história diplomática"), a consolidação da New Left e da abordagem revisionista está imbricada de tal forma que a análise de uma implica necessariamente referências à outra. Nesse sentido, cabe examinar brevemente algumas das principais características desse grupo de pesquisadores. 
Quem, afinal, eram os historiadores da New Left nos Estados Unidos? De modo geral, os historiadores norte-americanos identificados com a New Left eram jovens. Nascidos em sua maioria na década de 1930 (com exceção de Williams, que nasceu em 1921), os revisionistas e demais pensadores que se opunham à ortodoxia na década de 1960 haviam acabado de "concluir" a sua formação acadêmica. Haviam, portanto, convivido com uma Grande Depressão e ainda eram estudantes durante a Segunda Guerra Mundial. Nos termos de Smith,

alienados pela presumida e alegada falência da classe média de uma sociedade afluente, desiludida pela retórica da Guerra Fria, e estarrecida pelos riscos da destruição termonuclear, uma quantidade de intelectuais e acadêmicos em sua maioria jovens começou a atacar a política externa americana e a conclamar pela redução e eliminação dos compromissos no exterior de modo a concentrar na reforma interna. (Smith, 1970, p. 79)

Os historiadores revisionistas propunham uma nova interpretação sobre a Guerra Fria, sobre a sua origem e os seus desdobramentos, radicada numa nova visão de mundo e numa compreensão distinta sobre o papel exercido pelos Estados Unidos. Cabe, contudo, observar que, no contexto mais amplo da New Left, a crítica revisionista não se limitava à política externa norte-americana. Ela colocava em questionamento a própria organização social dos Estados Unidos, criticando principalmente a centralidade do expansionismo econômico e político para o modelo norte-americano de capitalismo. Ao abordar a crítica revisionista ao expansionismo norte-americano, Siracusa sustenta que

o argumento da New Left, colocado de forma simples, é que a política externa dos Estados Unidos deveria e poderia ser mais bem interpretada como um desdobramento da economia política capitalista americana, uma economia política, ademais, cuja dinâmica estrutural exigia tanto mercados em contínua expansão para um contínuo fluxo de mercadorias e de capital excedentes quanto o fácil acesso a matérias-primas num mundo de livre-comércio. Qualquer nação, sistema de organização política que ameaçasse esse objetivo se transformava [...] ou num objeto a ser cooptado por consentimento ou [num objeto] a ser eliminado. (Siracusa, 1993, p. 14) 
O ponto destacado por Siracusa, embora útil para abordar um dos aspectos importantes da interpretação revisionista, não deve ser tomado como síntese dessa corrente historiográfica. Como se pretende demonstrar, um dos aspectos mais interessantes da interpretação revisionista sobre a Guerra Fria é precisamente a crítica ao expansionismo enraizado na política externa dos Estados Unidos. Entretanto, os revisionistas foram além de uma crítica ao caráter expansionista da política externa norte-americana ao propor um questionamento do próprio modelo de organização social dos Estados Unidos, identificando também na política externa (mas não apenas nela) as consequências do mencionado expansionismo.

A maior parte da interpretação revisionista se baseou no trabalho seminal de William Appleman Williams, The tragedy of American diplomacy, originalmente publicado em 1959. Williams, que é considerado o "pai" do revisionismo, questionou as teses e os pressupostos da corrente ortodoxa, argumentando que a Guerra Fria deveria ser explicada precisamente no contexto do expansionismo norte-americano conduzido a partir do século XIX. Na interpretação revisionista, há uma relação histórica bem definida entre a Open Door Policy e uma série de conflitos e antagonismos decorrentes da defesa dos interesses imperialistas norte-americanos. Assim, a origem da Guerra Fria remonta, em linha com o revisionismo, às disputas entre os norte-americanos e os russos pela abertura dos mercados asiáticos no século XIX e se estende até a recusa da Casa Branca em reconhecer limites à fronteira norte-americana no mundo após a Segunda Guerra Mundial.

Entre as décadas de 1970 e 1980, consolidou-se nos Estados Unidos uma nova corrente historiográfica, autodenominada "pós-revisionismo", com a proposta central de dar por superada a fase revisionista de estudos sobre a Guerra Fria. Os dois principais representantes dessa corrente são o historiador norte-americano John Lewis Gaddis e o historiador norueguês Geir Lundestad

Em The United States and the origins of the Cold War, 1941-1947, publicado em 1972 e considerado o precursor da abordagem pós-revisionista, John Lewis Gaddis defendeu que os Estados Unidos ou a União Soviética não poderiam ser responsabilizados individualmente pelo início da Guerra Fria. Na obra, Gaddis desenvolveu uma crítica ao trabalho dos autores revisionistas (e a William Appleman Williams em parti- 
cular), que teriam falhado na tentativa de entender o papel da política soviética, após 1945, para o início da Guerra Fria. Gaddis contestou a tese revisionista de que o expansionismo norte-americano, desde o século XIX, seria o principal responsável pelas tensões que contribuíram para a Guerra Fria e criticou a hipótese de que a política soviética do pós-guerra era defensiva, argumentando que Stalin possuía condições e desejava expandir a influência da União Soviética sobre a Europa Ocidental (embora tenha concluído que a ocupação dos países europeus ocidentais não fosse, imediatamente após a Segunda Guerra, interessante para Moscou).

Segundo a interpretação pós-revisionista, os Estados Unidos teriam se tornado os "protetores do mundo ocidental" contra o expansionismo soviético, assumindo, por decorrência, uma postura imperialista, a pedido das nações que se sentiam ameaçadas pela União Soviética após a Segunda Guerra. Embora a União Soviética não desejasse e não pudesse expandir o seu poder por todo o mundo após a Segunda Guerra Mundial (uma ideia originalmente defendida por Gaddis, tendo sido posteriormente abandonada), o autoritarismo e a atração ideológica exercidos por Moscou ameaçavam a Europa e a Ásia, justificando a ação dos Estados Unidos.

O pós-revisionismo se converteu, de fato, numa interpretação da política externa dos Estados Unidos fiel às teses ortodoxas. Portanto, a retomada das ideias revisionistas é relevante como contraponto ao mainstream historiográfico dedicado à análise da política externa estadunidense, sobretudo se considerarmos a perspectiva inovadora introduzida por Williams.

\section{O "anticolonialismo imperial": a crise da década de 1890 e a expansão da fronteira econômica norte-americana por meio da Open Door Policy}

De acordo com Williams, a Open Door Policy, vigorosamente defendida pela política externa conduzida por Washington entre o final do século XIX e a primeira metade do século XX, foi a principal estratégia dos Estados Unidos para expandir a sua fronteira econômica pelo mundo, originalmente em resposta à crise econômica da década 
de 1890. Assim, a "tese da fronteira" proposta por Frederick Turner e Brooks Adams ${ }^{1}$ proveu os fundamentos ideológicos para uma política externa assentada na ideia de que a expansão era não apenas a saída para os problemas econômicos conjunturais dos Estados Unidos, mas a própria solução para a bem-sucedida reprodução do modelo democrático estadunidense. Essa perspectiva desempenhou, segundo Williams, papel central na guerra contra a Espanha em 1898 e nas diversas políticas conduzidas para conquistar mercados na Ásia. No entanto, observa o autor, foi precisamente o amplo sucesso da Open Door Policy que "engendrou os antagonismos criados por todos os impérios" (Williams, 1959, p. 125).

Williams defende que a visão dos Estados Unidos sobre si mesmos e sobre o mundo é composta de três ideias essenciais. A primeira é a ideia de que os Estados Unidos se mantiveram isolados em relação ao resto do mundo até outros países se voltarem para ele em busca de ajuda: primeiro Cuba (por ocasião da Guerra Hispano-Americana de 1898); depois a Europa em duas ocasiões (a Primeira e a Segunda Guerras Mundiais); e, por fim, o mundo (na defesa contra a União Soviética, durante a Guerra Fria). Uma segunda ideia se baseia na proposição de que os Estados Unidos se mantiveram isolacionistas e anti-imperialistas por toda a sua história (com exceção de um curto intervalo de tempo, durante a Guerra Hispano-Americana). Por fim, uma terceira ideia sustenta que uma combinação singular entre poder econômico, poder intelectual, objetividade e rigor moral permitiu aos Estados Unidos confrontar os inimigos da paz e do progresso em todo o mundo, de modo a construir um mundo melhor sem, no entanto, incorrer numa política imperialista ao longo desse processo (Williams, 1959, p. 117).

Para Williams, a três ideias que compõem o imaginário norte-americano sobre o papel dos Estados Unidos no mundo não estão completamente equivocadas. De fato, propõe o autor, os Estados Unidos se envolveram nos assuntos internacionais de forma gradual, voltando-se primeiramente, do ponto de vista histórico, para os seus próprios problemas domésticos antes de se ocuparem das questões externas. Do mesmo modo, os Estados Unidos sustentaram posições anti-imperialistas em

1 Uma discussão mais detalhada sobre a "tese da fronteira" e as suas implicações para a política externa dos Estados Unidos pode ser encontrada em Combat (2017). 
períodos específicos de sua história, sobretudo em épocas em que se imaginava que a preservação da sociedade norte-americana dependia do isolamento em relação às intrincadas disputas que polarizavam a Europa. Por fim, Williams destaca que os Estados Unidos, de fato, já impuseram diversos limites ao seu próprio poder, baseados na crença de que esses limites eram necessários à preservação da própria democracia (Williams, 1959, p. 117).

Contudo, Williams argumenta que as três ideias tradicionais que compõem a visão dos Estados Unidos sobre si mesmos e sobre o mundo são apenas uma parte da realidade. Afinal, se elas explicassem toda a experiência histórica do envolvimento dos Estados Unidos em questões internacionais, as implicações da política externa norte-americana no século XX dificilmente poderiam ser explicadas, justamente porque contradizem o ideário de uma nação prioritariamente isolacionista, anti-imperialista e comprometida com a defesa da paz.

Williams propõe, então, que uma revisão da história norte-americana no século XX deve partir da ideia de que os "norte-americanos se viam como um império desde o princípio da sua existência nacional - como parte da própria consciência assertiva que culminou na Revolução Americana" (Williams, 1959, p. 118). A afirmação de que a concepção de império estava presente na origem dos Estados Unidos pode, reconhece Williams, parecer estranha diante do ideário isolacionista fortemente enraizado na história norte-americana. Mas, como ressalta o autor, tendo vivido numa época de impérios e tendo sido ele mesmo parte do Império britânico, os Estados Unidos dos "pais fundadores" enxergavam a si mesmos como parte daquele sistema imperial, sobretudo diante dos imperativos em suas delicadas relações com a Grã-Bretanha.

Entretanto, Williams sublinha que, embora a visão de império fosse muito natural e atraente para os "pais fundadores", ela impunha uma série de contradições ao projeto de formação de uma nova nação nos moldes idealizados durante a Revolução Americana. A teoria política e as ideias que guiavam os Estados Unidos durante e logo após a Guerra de Independência estavam assentadas no pressuposto de que uma democracia só era viável num Estado territorialmente pequeno. Essa concepção, firmemente enraizada no imaginário político dos "pais fundadores", impunha um sério dilema aos Estados Unidos da América, 
uma vez que qualquer expansão implicava a imediata extensão territorial do país e colocava, portanto, em risco o projeto de uma democracia. A solução encontrada decorreu, segundo Williams, de uma nova interpretação sobre a conciliabilidade entre o império e a democracia. Assim, liderados pelo presidente James Madison (1809-1817), os "pais fundadores"

tentaram resolver a contradição entre a sua motivação pelo império e a sua política desenvolvendo uma teoria própria que afirmava que o republicanismo democrático poderia ser aperfeiçoado e sustentado somente através de uma política externa imperial. (Williams, 1959, p. 118)

A consolidação, no imaginário político e social norte-americano, da conciliabilidade entre a democracia e uma política externa expansionista imperial dependia, certamente, da forma como tal ideia seria apresentada e defendida. Os benefícios subjacentes a essa concepção deveriam, portanto, ser inequívocos se fosse pretendida a assunção desse novo ideário pela sociedade norte-americana. E assim o foi. Segundo Williams, o presidente James Madison liderou a defesa do principal "guia para a política e para ação em seu próprio tempo" ao sustentar a primazia da expansão territorial para os Estados Unidos. Assim, sintetiza Williams,

a expansão era essencial para mitigar os conflitos econômicos ao prover um império para a exploração e para o desenvolvimento, e para interpor longas distâncias (e,portanto, dificuldades e atrasos em sustentar novos antagonismos) entre uma facção [social] e o resto da nação e o próprio governo. (Williams, 1959, p. 118)

O ideal expansionista defendido por Madison alcançou grande projeção nos Estados Unidos, no começo do século XIX, e, na prática, orientou o processo de avanço das fronteiras norte-americanas para o Oeste. Mas, como argumenta Williams, a inquestionável preponderância do ideal expansionista (sobretudo no que se refere à política externa) sobre as demais ideias que preconizavam a incompatibilidade entre um Estado territorialmente grande e uma sociedade verdadeiramente democrática só foi alcançada ao final do século XIX, durante a depressão econômica da década de 1890. Somente então os Estados Unidos cons- 
tataram que a sua fronteira econômica interna estava esgotada, de modo que "uma nova expansão", agora para o mundo, "era o melhor, senão o único, caminho para sustentar a sua liberdade e prosperidade" (Williams, 1959, p. 119).

A grande crise da década de 1890 marcou não apenas o esgotamento das fronteiras econômicas internas norte-americanas, mas também uma transformação substancial do capitalismo estadunidense, com o florescimento das grandes corporações e o profundo escasseamento das oportunidades de valorização do capital. Williams atenta para uma série de explicações que surgiram na tentativa de dar conta da origem da crise e de apontar possíveis soluções. A maior parte das explicações compartilhava o mesmo diagnóstico sobre a origem da crise: o sucesso do modelo econômico e político norte-americano era tamanho, que os Estados Unidos terminaram por produzir mais do que poderiam consumir. As soluções para o problema, entretanto, eram divergentes. Alguns acreditavam que reformas pontuais colocariam a economia norte-americana nos trilhos, enquanto outros grupos defendiam que os problemas econômicos seriam resolvidos mais rapidamente sem a intervenção do Estado. Todavia, essa interpretação sobre o embate das propostas para o equacionamento da crise esconde, segundo Williams, a grande preocupação dos Estados Unidos com a sua política externa já a partir do final do século XIX.

Williams defende que, ao final do século XIX, os Estados Unidos já acreditavam que "a política externa poderia e deveria desempenhar um papel importante - senão crucial - na recuperação da depressão e na prevenção de futuras crises" (Williams, 1959, p. 120). Um amplo consenso social ecoava a ideia de que uma política externa expansionista era a solução para a crise da década de 1890 . De um lado, industriais, banqueiros, fazendeiros e os demais grupos econômicos com poder político "explicavam a depressão e a sublevação social como o resultado da falta de mercados para os seus produtos específicos - fossem eles aço, capital ou trigo" (Williams, 1959, p. 120). De outro, uma ideia mais ampla, alicerçada na "tese da fronteira" proposta por Frederick Turner e Brooks Adams, "explicava a democracia e a prosperidade no passado da América como o resultado de uma expansão dentro do continente e, em menor grau, mar afora pelos mercados do mundo" (Williams, 1959, p. 120). As duas ideias, em síntese, concluíam que a expansão era o caminho para 
acabar com a sublevação social, preservar a democracia e restaurar a prosperidade dos Estados Unidos na virada do século.

Williams reafirma, portanto, a centralidade da "frontier thesis" proposta por Turner e Adams ao final do século XIX para explicar o casamento entre o expansionismo, a democracia e a prosperidade econômica que fundamentou, desde então, a política externa dos Estados Unidos.

Williams ressalta que, não obstante a ampla base de apoio social sobre a necessidade de uma política externa expansionista para resguardar a democracia e restaurar a prosperidade econômica dos Estados Unidos, algumas dissonâncias ainda emergiam entre grupos com interesses distintos. Assim, por exemplo, os empresários prejudicados pela rápida concentração de capital, observada nos Estados Unidos ao final do século XIX, recorriam às ideias de Turner ao defender uma legislação que impedisse uma competição predatória entre os capitais (leis antitrustes). Por outro lado, as grandes corporações industriais e os bancos norte-americanos recorriam às ideias de Adams ao defender uma política externa mais ativa na busca por novos mercados mundo afora. Outros grupos viam ainda o expansionismo como a melhor forma de acabar com os conflitos entre o capital e os trabalhadores, ao identificar na expansão das fronteiras econômicas a chave para a reprodução bem-sucedida da economia norte-americana. De toda forma, todos os grupos partiam do pressuposto de que uma política externa expansionista era primordial para a reprodução do próprio modelo social estadunidense.

Williams explica a origem da Guerra Hispano-Americana de 1898 precisamente no contexto do amplo consenso social norte-americano sobre a necessidade de uma política externa expansionista. $O$ autor enfatiza que a guerra contra a Espanha, ao final do século XIX, envolvia uma série de interesses de diferentes grupos sociais norte-americanos. Enquanto várias corporações viam na guerra contra os espanhóis um conjunto objetivo de oportunidades de negócios (traduzidas como simples aumento da demanda), outros grupos ligados ao setor agrário enxergavam o conflito como uma oportunidade para monetizar a prata (ou seja, como uma chance para introduzir um novo padrão monetário que desatasse a economia norte-americana dos rígidos limites impostos pelo padrão-ouro) e, portanto, para expandir as suas exportações por outras regiões do mundo até então controladas pelo Império britânico 
(Williams, 1959, p. 123). Outras empresas norte-americanas, ainda que em menor escala, eram diretamente afetadas pelos problemas políticos em Cuba, de modo que a independência da ilha soava como uma alternativa para tirar a Espanha do caminho de seus negócios.

O amplo apoio social norte-americano à Guerra Hispano-Americana decorria ainda mais centralmente, segundo Williams, da percepção de que a expansão do comércio exterior, ao longo da década de 1890, estava realmente desempenhando um papel importante na recuperação econômica dos Estados Unidos. Com base nessa percepção, diversos líderes políticos e econômicos dos Estados Unidos mostravam-se verdadeiramente preocupados pelas sinalizações de que as potências colonialistas europeias, a Rússia e o Japão desejavam conquistar as ricas fronteiras econômicas da China. A maior parte desses líderes norte-americanos, influenciados pelas ideias de Brooks Adams, olhava para a Ásia, e para a China em especial, como a principal fronteira para a expansão do capital no além-mar, como a "terra prometida" àqueles que buscavam novas oportunidades econômicas. Precisamente por essa razão, de acordo com Williams, a sociedade norte-americana apoiava uma guerra contra a Espanha pela libertação de Cuba e, ainda mais centralmente, das Filipinas, pois uma guerra contra uma grande potência colonialista era essencial para provar à Europa que os Estados Unidos estavam verdadeiramente comprometidos com a defesa de seus interesses no continente americano e no restante do mundo.

A reafirmação da Doutrina Monroe, em 1898, na Guerra Hispano-Americana, foi, na interpretação proposta por Williams, a mais clássica demonstração do "anticolonialismo imperial" que orientava então a política externa conduzida por Washington. Ao combater o colonialismo espanhol em Cuba e nas Filipinas, os Estados Unidos reafirmavam os seus próprios interesses expansionistas imperiais e sinalizavam a disposição de ir à guerra para defender a expansão de suas fronteiras econômicas, fossem elas as fronteiras no próprio continente americano ou as longínquas fronteiras asiáticas.

A asserção de que a guerra contra a Espanha ao final do século XIX estava respaldada por um amplo consenso social dentro dos Estados Unidos não significa, de acordo com Williams, a existência de um amplo consenso sobre a forma como a política externa expansionista deveria ser conduzida. Se os fins estavam claros, pesavam dúvidas sobre os 
meios e, sobretudo, sobre o preço a se pagar por uma política externa que poderia acabar se tornando tão colonialista quanto aquela conduzida pelos países europeus. Três grupos políticos distintos defendiam visões, aparentemente irreconciliáveis, sobre a forma como Washington deveria defender os seus interesses no exterior. O primeiro era liderado porTheodore Roosevelt, um político republicano sem grande expressão dentro do partido até conquistar o governo do estado de Nova York. Voluntário na Guerra Hispano-Americana (Roosevelt era não penas um político, mas também coronel reformado do Exército dos Estados Unidos), Roosevelt liderava o grupo dos “imperialistas”, que defendiam uma política externa mais incisiva e, se necessário, belicista, para defender os interesses econômicos dos Estados Unidos pelo mundo. Um segundo grupo, os "anti-imperialistas", era liderado por William Jennings Bryan, candidato democrata em três eleições presidenciais (saindo derrotado de todas). Eles defendiam uma política externa igualmente comprometida com a expansão dos interesses econômicos norte-americanos, que deveria, entretanto, evitar conflitos diretos contra as potências colonialistas europeias, enfatizando, alternativamente, a necessidade de uma política comercial mais ativa. Um terceiro grupo, que se aproximava mais dos "anti-imperialistas", era formado por intelectuais e empresários que "se opunham ao colonialismo tradicional e advogavam alternativamente a política de portas abertas para a expansão econômica internacional dos Estados Unidos" (Williams, 1959, p. 125, grifo nosso).

A ênfase, na diferenciação dos três grupos que disputavam primazia na definição da forma como a política externa expansionista norte-americana seria conduzida, recai precisamente no "anticolonialismo" advogado pelo terceiro grupo. É precisamente na defesa do "anticolonialismo" que Williams identifica a consolidação da Open Door Policy como a principal diretriz da política externa expansionista conduzida pelos Estados Unidos a partir do final do século XIX. Williams observa que, por muito tempo, na historiografia norte-americana que trata da crise da década de 1890, a Open Door Policy foi tomada como uma iniciativa "fútil e inocente" num mundo guiado pela cruel lógica colonial, tendo sido, dentro dessa visão, amplamente malsucedida. Para o autor, entretanto,

a Open Door Policy foi de fato um brilhante golpe estratégico que levou à 
extensão gradual do poder econômico e político norte-americano através do mundo. Se ela falhou em última instância, não foi porque ela era tola ou fraca, mas porque ela foi tão bem-sucedida. O império que foi construído de acordo com a estratégia e as táticas das Open Door Notes engendrou os antagonismos criados por todos os impérios, e é essa oposição que colocou tantas dificuldades [no caminho da] diplomacia norte-americana na [primeira] metade do século XX. (Williams, 1959, p. 125)

Portanto, dentro da interpretação proposta por Williams, a consolidação e o sucesso da Open Door Policy como principal princípio norteador da política externa expansionista imperial dos Estados Unidos explicam, em grande medida, os atritos e os conflitos protagonizados por Washington mundo afora, ao final do século XIX e ao longo da primeira metade do século XX.

A primazia dos interesses imperiais dos Estados Unidos a partir da firme defesa do princípio da Open Door Policy não passava despercebida pelas potências colonialistas europeias. Enquanto, do lado norte-americano, a imprensa aclamava a Open Door Policy como uma "nova doutrina estabelecida para a China [e] destinada a ser tão importante quanto a Doutrina Monroe foi para os norte-americanos no século passado", do lado europeu, a imprensa alemã sublinhava que "os americanos consideravam, em certo sentido, toda a China como a sua esfera de interesse" (Williams, 1959, p. 127-128). O resultado desse conflito de interesses entre as potências imperialistas é, como enfatiza Williams em diversas passagens de sua obra, um fator-chave para entender os antagonismos engendrados pela política externa norte-americana desde o final do século XIX.

Williams objeta também uma série de críticas que apontam a suposta irrelevância do princípio da Open Door Policy para a política externa norte-americana. De acordo com o autor, aqueles que sustentam a irrelevância ou o fracasso da Open Door Policy como princípio norteador da política externa de Washington desde a década de 1890,

desconsideram o seu profundo enraizamento no passado norte-americano e a sua importância naquela época [fim do século XIX], e falham por não perceber que a política [da Open Door Policy] expressava a estratégia básica da expansão secular e imperial dos Estados Unidos no século XX. Quando combinada com a ideologia de um Destino Manifesto industrial, 
a história das Open Door Notes se transforma na história das relações exteriores norte-americanas de 1900 a 1958. (Williams, 1959, p. 128)

Williams sinaliza que a centralidade da Open Door Policy para a política externa dos Estados Unidos foi tamanha a ponto de ela ser convertida numa nova versão industrial da ideologia do Destino Manifesto. Se, um século antes, os norte-americanos viam a si mesmos como o "povo eleito" por Deus para conquistar a fronteira Oeste dos Estados Unidos, então, ao final do século XIX e ao longo da primeira metade do século XX, esse mesmo povo estava destinado, pelos desígnios de sua pujante indústria, a expandir as suas fronteiras econômicas pelo mundo.

Na próxima seção, analiso a interpretação do historiador revisionista Walter LaFeber sobre os conflitos engendrados pela política externa norte-americana ao longo do processo de reafirmação da Open Door Policy na Ásia.

\section{Os conflitos com as potências colonialistas pela abertura da Ásia na interpretação de Walter LaFeber}

A interpretação proposta por William Appleman Williams sobre a política externa dos Estados Unidos entre o final do século XIX e a primeira metade do século XX rompeu a hegemonia da corrente historiográfica ortodoxa e influenciou uma geração de historiadores que, assim como Williams, propunham uma interpretação alternativa para a política externa expansionista orientada pela Open Door Policy.

Dentre os representantes da corrente revisionista, Walter LaFeber alcançou notoriedade exatamente por aprofundar as ideias originalmente propostas por Williams. LaFeber partiu de uma interpretação muito semelhante à de Williams, identificando na política externa expansionista conduzida porWashington a origem dos conflitos que polarizaram os Estados Unidos e as potências colonialistas nas disputas pela abertura dos mercados asiáticos (na virada no século XIX para o século XX).

O objetivo dessa seção é analisar a interpretação de LaFeber sobre a política externa dos Estados Unidos com a Ásia na busca pela expansão das fronteiras econômicas norte-americanas, entre o final do século XIX e a primeira década do século XX. 


\section{Open Door, Closed Asia: a política externa dos Estados Unidos para a China na década de 1890}

Herdeiro direto da primeira fase do debate revisionista, LaFeber partiu da interpretação proposta por Williams (de quem foi aluno e orientando durante o doutorado na Universidade de Wiscosin, em Madison) sobre a política externa expansionista conduzida pela Casa Branca desde o final do século XIX, para explicar a origem dos conflitos entre Washington e Moscou ao longo do século XX. LaFeber identificou, assim, na década de 1890, a consolidação de uma política externa orientada pela Open Door Policy, centralmente comprometida com a expansão mundial das fronteiras econômicas dos Estados Unidos. Ao analisar a condição dos Estados Unidos após a Guerra Hispano-Americana de 1898, LaFeber observou que

após o triunfo sobre a Espanha em 1898 conferir aos Estados Unidos novas possessões no Caribe e no Pacífico Ocidental, o subsecretário de Estado, John Bassett Moore, observou que a nação havia se deslocado "de uma posição de liberdade comparativa em relação ao emaranhamento [de relações políticas na Europa] para uma posição que é comumente chamada de potência mundial [...]. Onde antes só tínhamos interesses comerciais, também temos agora interesses territoriais e políticos”. (LaFeber, 1989, p. 182)

Para LaFeber, a afirmação internacional dos interesses norte-americanos a partir do final do século XIX implicava, como consequência da Open Door Policy, uma série de conflitos com as antigas potências imperialistas e com os seus sistemas de privilégios coloniais que limitavam a expansão das fronteiras econômicas dos Estados Unidos. Os conflitos engendrados na busca pela abertura dos mercados asiáticos são, nessa interpretação, emblemáticos. A China em especial, como observado por diferentes policymakers norte-americanos na primeira metade do século XX, era a grande fronteira para os Estados Unidos no mundo e um desafio central para a política externa de diversos governos norte-americanos. O objetivo desta seção é apresentar a interpretação de LaFeber sobre as principais diretrizes da política externa expansionista dos Estados Unidos entre o final do século XIX e a primeira década do século XX, destacando os conflitos alimentados com outros países que também nutriam interesses nos prósperos mercados chineses. 
$\mathrm{Na}$ visão de LaFeber, a guerra contra a Espanha, ao final do século XIX, abriu aos Estados Unidos uma oportunidade muito aguardada de projetar o poder norte-americano sobre a Ásia. Ao chegar à Casa Branca, em 1897, o presidente William McKinley enfrentou duas grandes crises na política externa, cuja solução contribuiu decisivamente para a consolidação da Open Door Policy.

Em 1894-1895, a política tarifária protecionista instaurada no governo do presidente Stephen Grover Cleveland havia fechado o mercado norte-americano aos produtos cubanos (principalmente o açúcar). Como resultado, Cuba mergulhou numa profunda crise econômica, que reacendeu a oposição contra o sistema colonialista espanhol ao qual os cubanos estavam submetidos (e contra o qual já haviam se rebelado entre 1868 e 1878). Embora apoiassem o movimento de oposição ao colonialismo espanhol, os Estados Unidos não formalizaram o apoio ao governo provisório cubano, temendo que a deposição da autoridade espanhola sobre a ilha implicasse perdas para os cerca de US\$ 50 milhões que empresas norte-americanas mantinham investidos em Cuba (LaFeber, 1989, p. 185). Contudo, Washington tinha receio de que a completa ausência de apoio aos rebeldes cubanos (em sua maioria, formados por membros da elite oligárquica da ilha, que controlava as grandes fazendas produtoras de açúcar) implicasse uma radicalização do movimento, que poderia se deslocar para a esquerda e fugir tanto do controle espanhol quanto do controle norte-americano. Alternativamente, os Estados Unidos preferiam pressionar Madri a relaxar o controle sobre Cuba, concedendo à elite cubana maior autonomia nos assuntos internos.

A Espanha, contudo, manteve-se firme na recusa em reconhecer qualquer autoridade dos cubanos sobre o seu próprio país. A justificativa mais clara para a resistência espanhola, de acordo com LaFeber, estava na própria decadência de seu império: ao final do século XIX, pouco restava a Madri além de Cuba, Porto Rico, Guam e as Filipinas. O governo espanhol reagiu, então, à crise em sua colônia cubana com o envio de 150 mil soldados, que tentaram, sem sucesso, conter os rebeldes. À medida que a guerra entre espanhóis e cubanos se intensificava, a pressão sobre a Casa Branca também crescia. Jornais passaram a noticiar a destruição de instalações de empresas norte-americanas em Cuba, ao mesmo tempo em que exclamavam a inferioridade da Espanha e a necessidade de levar aos cubanos a civilidade estadunidense. 
Não obstante a pressão do Congresso e da imprensa, a Casa Branca relutou, até fevereiro de 1898, em se posicionar claramente na disputa entre Cuba e Espanha. O presidente McKinley temia que uma guerra mergulhasse os Estados Unidos numa nova depressão. Os conselheiros econômicos do presidente o advertiam que uma intervenção militar contra os espanhóis só poderia ser financiada com a ampliação da base monetária do país, que poderia implicar a desvalorização do dólar e ameaçar o acesso dos Estados Unidos ao mercado de crédito internacional. O presidente temia ainda a possibilidade de que uma provável vitória contra Madri fosse seguida de pressão pela anexação de Cuba aos Estados Unidos. LaFeber observa que, ao final do século XIX, Washington já enfrentava grandes problemas sociais internos ao lidar com o grande fluxo de imigrantes e com a escalada de movimentos de oposição aos negros em diversos estados norte-americanos.

Madri cedeu, parcialmente, à pressão reformista de Washington, mas a decisão de aumentar a autonomia dos cubanos chegou muito tarde e de forma muito modesta. Em fevereiro de 1898, o navio de guerra norte-americano USS Maine adentrou o Porto de Havana, com o objetivo de proteger os cidadãos e os demais interesses norte-americanos na ilha. Uma explosão misteriosa, no entanto, afundou o navio e foi o estopim para a entrada dos Estados Unidos no conflito. A imprensa norte-americana imediatamente noticiou o fato como um ato de guerra da Espanha contra os Estados Unidos, embora nenhum ato de sabotagem contra o navio tenha sido comprovado.

Enquanto enfatizava a necessidade de uma investigação sobre a explosão do USS Maine antes de declarar guerra à Espanha, McKinley assistiu à deflagração de uma segunda crise, que afetava potencialmente os interesses mais caros da política externa norte-americana. Em 1897, a Alemanha impusera limites à expansão japonesa na China, proibindo a anexação de territórios. Adicionalmente, Berlim estabeleceu o seu controle sobre o Porto de Kiaochow, a principal rota de acesso à próspera região chinesa da Manchúria. O porto controlado pelos alemães também era a principal rota de comércio entre os Estados Unidos e a China, além de um entreposto para os navios britânicos. Tão logo Berlim restabeleceu um sistema de preferências coloniais sobre a Manchúria, outras potências europeias e o Japão iniciaram disputas pelo controle de outras regiões do país, fechando, assim, mais uma vez, as portas da Ásia aos interesses econômicos dos Estados Unidos. 
Embora reconhecesse a dimensão dos problemas na China, McKinley acreditava que tinha de resolver primeiro a crise em Cuba antes de se voltar aos desafios na Ásia. Uma possível solução conjunta para os dois problemas foi, contudo, vislumbrada em 1898. As insurreições contra a Espanha iniciadas em Cuba se disseminaram também pelas outras colônias espanholas. Quando os rebeldes filipinos se voltaram aos Estados Unidos em busca de apoio contra Madri, a Casa Branca rapidamente percebeu a possibilidade ímpar envolvida nas circunstâncias: as Filipinas poderiam ser transformadas numa base para a defesa dos interesses dos Estados Unidos na Ásia.A crise iniciada pelas disputas entre a Alemanha e o Japão ameaçava diretamente a política de abertura da China aos interesses norte-americanos, de modo que um posto avançado dos Estados Unidos cravado no mar da China Meridional era um trunfo do qual nenhum presidente norte-americano poderia abrir mão.

A Casa Branca preparou-se, então, para equacionar dois problemas num só movimento da política externa. Tomando a destruição do navio USS Maine como desculpa, McKinley demandou US\$ 50 milhões ao Congresso para mobilizar uma ofensiva contra a Espanha. Com o apoio do Congresso e da elite empresarial nova-iorquina ${ }^{2}$, a Casa Branca apresentou, em março de 1898, uma série de exigências ao governo espanhol, dentre elas a negociação, com intermediação dos Estados Unidos, da independência de Cuba. Diante da negativa espanhola, os Estados Unidos declararam guerra à Espanha em abril de 1898. McKinley confidenciara aos seus conselheiros que não desejava a guerra, mas as circunstâncias deixavam poucas alternativas.

O conflito com a Espanha foi breve. Três meses após o início da guerra e a um custo total para os Estados Unidos de US\$250 milhões (LaFeber, 1989, p. 196), em 12 de agosto de 1898, a Espanha assinou um tratado de paz com Washington, reconhecendo a independência de Cuba (que permaneceu sob a tutela dos Estados Unidos). Como "espólio de guerra”, os Estados Unidos também receberam o controle sobre Guam,

2 Em 25 de março de 1898, McKinley recebeu um telegrama de um amigo de Nova York, no qual era mencionado: “as grandes corporações aqui acreditam agora que nós teremos uma guerra. Acredite que todas [as corporações] receberão [a guerra contra a Espanha] como um alívio a todo esse suspense" (LaFeber, 1989, p. 189). 
Porto Rico e as Filipinas ${ }^{3}$ - onde pretendiam fundar uma base para a defesa dos interesses norte-americanos na Ásia.

Os beneficios da Guerra Hispano-Americana para Washington foram inequívocos. Logo após a derrota contra a Espanha, McKinley e o seu secretário adjunto da Marinha,Theodore Roosevelt, se empenharam em derrubar as barreiras protecionistas que isolavam Cuba do mercado norte-americano, de modo que, já em 1903, o açúcar e os minérios cubanos voltaram a entrar nos Estados Unidos, enquanto os produtos agrícolas e industriais do vizinho do Norte fluíam para Cuba. Assim, a corrente de comércio entre os Estados Unidos e Cuba saltou de US\$27 milhões em 1897 para mais de US\$ 300 milhões em 1917 (LaFeber, 1989, p. 198).

$\mathrm{O}$ controle sobre as Filipinas provou-se igualmente útil à política externa expansionista norte-americana. Ao final da década de 1890, a China estava dividida por interesses contrários à Open Door Policy. Russos e alemães reivindicavam colônias em regiões estratégicas do país. Britânicos, franceses e japoneses lutavam para defender os seus respectivos interesses comerciais conflitantes em regiões da China, que interessavam igualmente aos Estados Unidos. Uma base militar norte-americana cravada nas Filipinas transformou-se na linha de frente da luta pela expansão das fronteiras dos Estados Unidos na Ásia.

Não obstante o aumento das disputas pelo mercado chinês, os Estados Unidos conseguiram firmar os seus interesses nessa próspera fronteira econômica. Assim, entre 1895 e 1900, as exportações norte-americanas para a China quadruplicaram, alcançando US\$ 15 milhões (LaFeber, 1989, p. 205). Esse volume ainda representava menos de 2\% das exportações totais dos Estados Unidos ao final do século XIX, mas os empresários norte-americanos tinham em vista o rápido crescimento da economia chinesa e o potencial de um mercado que já somava centenas de milhões de habitantes. Segmentos da indústria norte-americana, na realidade, já tinham a China como principal mercado consumidor

3 A independência das Filipinas em relação à Espanha foi seguida por uma guerra contra os Estados Unidos, que se estendeu de 1899 a 1902. Na Guerra Filipino-Americana, da qual os norte-americanos saíram vitoriosos, os Estados Unidos tiveram de enfrentar os revolucionários filipinos liderados por Emilio Aguinaldo, que não desejavam se submeter a Washington e a sua proposta de "tutorar" as Filipinas (mantendo-a, na prática, submetida a um regime colonial). 
fora dos Estados Unidos antes mesmo da virada do século. Esse era o caso da indústria têxtil e também do petróleo, do ferro e dos produtos de aço. A indústria do algodão, que na depressão de 1873-1897 amargara uma profunda contração, floresceu novamente, retomando o posto de centro dinâmico da economia do Centro-Sul dos Estados Unidos.

A edificação da política externa dos Estados Unidos para a China foi, de acordo com LaFeber, diretamente influenciada pelo secretário de Estado, John Hay, que dispunha de uma condição ímpar na sociedade norte-americana: transitava com igual destreza entre os membros do Capitólio e a elite industrial do país. Nascido em Indiana, em 1838, tornou-se assistente e secretário particular de Abraham Lincoln com apenas 23 anos. O cargo lhe conferiu grande prestígio ao longo da carreira e também acesso direto à pujante indústria siderúrgica norte-americana, da qual se tornou porta-voz. Já no governo de McKinley, Hay alcançou notoriedade ao assumir o cargo de embaixador na Grã-Bretanha, país pelo qual expressava grande admiração. Para Hay, os Estados Unidos e a Grã-Bretanha tinham de trabalhar lado a lado para combater a Rússia, a França e a Alemanha em seu projeto de "dividir e reduzir a China a um sistema de províncias tributárias” (LaFeber, 1974, p. 502-503).

As palavras de Hay ecoaram nos Estados Unidos ao final do século XIX e se adequaram com precisão à visão de McKinley sobre a importância da China na política externa norte-americana. Assim, em 1898, o presidente fez o convite para que Hay assumisse o Departamento de Estado e a linha de frente da disputa pelos mercados chineses. A primeira iniciativa de Hay como secretário de Estado foi a publicação de uma carta (conhecida como a primeira Open Door Note), em 1899, endereçada a São Petersburgo, Paris, Berlim e Tóquio, na qual pedia às potências colonialistas que dessem aos norte-americanos o mesmo tratamento tributário e comercial concedido aos seus respectivos cidadãos que negociavam na China, cobrando tarifas iguais nos portos e ferrovias localizados nas chamadas "esferas de interesses" que cada potência clamava para si no território chinês. Hay também enfatizava a necessidade de um sistema tributário unificado em toda a China e destacava que o próprio governo chinês deveria ser o responsável pela cobrança dos impostos. Por fim, o secretário de Estado insistia na importância da integridade territorial chinesa, opondo-se, portanto, às demandas pela 
autonomia de algumas regiões controladas pelos europeus e pelos russos (Sugita, 2003, p. 10).

As demandas de Hay não foram recebidas com entusiasmo pelas potências que disputavam o controle dos mercados chineses. Mas tampouco despertaram aberta oposição. Àquela altura, estava clara a disposição de Washington de ir à guerra contra uma potência europeia do calibre da Espanha para defender os seus próprios interesses. A Guerra Hispano-Americana reforçara no imaginário dos líderes mundiais a condição dos Estados Unidos como uma potência econômica e militar emergente e, embora não dispusesse de uma significativa presença militar na Ásia, o controle sobre as Filipinas colocava nas mãos de Washington um trunfo estratégico no mar da China Meridional.

Ao final do século XIX, os russos não se julgavam fortes o suficiente para desafiar Washington, que contava com o apoio de Londres e Tóquio. Hay, então, provou as suas habilidades diplomáticas, conquistando, primeiro, o apoio de britânicos e japoneses para a sua política de "portas abertas" na Ásia. Em seguida, cooptou os franceses. Aos alemães e russos restava, então, aquiescer ou se voltar contra todos os aliados da Casa Branca. Dessa forma, por convencimento ou coerção, os Estados Unidos conquistaram o apoio à desejada Open Door Policy na China. O establishment político e econômico norte-americano felicitou o secretário de Estado pela bem-sucedida diplomacia na Ásia e o nome de Hay chegou a ser cogitado para a Casa Branca.

Os Estados Unidos tinham ciência de que a abertura dos mercados asiáticos em condições de igualdade tarifária e comercial para todas as potências não significava uma competição igualitária. Enquanto as antigas potências colonialistas europeias lutavam contra os efeitos deletérios do desmantelamento de seus respectivos impérios e se esforçavam para manter o seu poder em outras regiões do mundo, os Estados Unidos emergiram da grande depressão da segunda metade do século XIX como uma moderna potência industrial. Assegurado um ponto de partida em comum para todas as potências, as indústrias norte-americanas teriam condições de rapidamente conquistar os principais mercados da China. Essa era, em síntese, a meta mais ambiciosa de McKinley e Hay: eles queriam exportar para toda a China, e não exclusivamente para uma região, a qual poderiam ter controlado caso se enquadrassem no antigo sistema de preferências coloniais. 
LaFeber nota que, apesar do inquestionável sucesso econômico da política externa conduzida por McKinley e Hay na Ásia, a Open Door Policy gerou uma série de conflitos e consolidou importantes rivalidades entre os Estados Unidos, a Rússia e as demais potências que disputavam os mercados chineses. Essas rivalidades se estenderam para além das potências que disputavam o controle de rotas de comércio e de mercados consumidores, chegando até aqueles que eram mais diretamente prejudicados por essa intricada disputa política e comercial: os próprios chineses. Como destaca o autor, um grupo social chinês xenófobo e militarizado, conhecido como Boxers, passou a atacar estrangeiros e as suas propriedades (LaFeber, 1989, p. 208).

$\mathrm{O}$ aumento da animosidade chinesa com a ingerência das grandes potências foi seguido pelo envio de tropas norte-americanas para proteger os interesses dos Estados Unidos na China. Para Washington, tornou-se evidente que a Rússia, a Alemanha e mesmo o Japão estavam aproveitando o aumento das tensões com os Boxers para justificar a "proteção" de algumas regiões da China e a interrupção da entrada de estrangeiros. Portanto, quando a Casa Branca autorizou o envio para a China de 5 mil soldados norte-americanos que já estavam nas bases em Manila, nas Filipinas, o secretário de Estado, Hay, valeu-se do poder militar para garantir o apoio das demais potências à política externa estadunidense. Um documento de 3 de julho de 1900, encaminhado pelo Departamento de Estado norte-americano aos países que mantinham relações comerciais com o chineses, exigia que todas as potências se comprometessem a preservar "a integridade territorial e administrativa da China” (LaFeber, 1989, p. 209). Essa questão se convertera no centro do embate entre as potências.

Mais uma vez, os interesses europeus, russos e japoneses na China tiveram de ceder espaço às imposições norte-americanas. McKinley enviara, entre 1900 e 1901, sucessivos destacamentos militares e uma esquadra da Marinha norte-americana para patrulhar a China. Como ressalta LaFeber,

em 1901, a Rússia parecia enquadrada [na política externa norte-americana]. O presidente [dos Estados Unidos] tinha aumentado substancialmente o seu poder executivo ao enviar milhares de tropas norte-americanas para o território da China sem se preocupar em consultar o Congresso. E as 
potências estrangeiras mantiveram a dinastia Manchu como governante da China [em linha com a demanda norte-americana], embora aquela vitória tenha durado pouco. Em 1911, conflitos internos emergiram novamente, e dessa vez a dinastia [chinesa de Manchu] desapareceu em meio ao começo da Revolução Chinesa. (LaFeber, 1989, p. 209)

O enquadramento dos europeus, russos e japoneses na Open Door Policy defendida pelos norte-americanos não significava, como bem observa LaFeber, o equacionamento das tensões entre as grandes potências que disputavam os mercados chineses. Ao contrário: em agosto de 1900, em meio a uma acirrada campanha pela reeleição nos Estados Unidos, McKinley teve de lidar com uma nova disputa contra o Império russo, que nunca deixou de reivindicar a criação de uma colônia na China. Dessa vez, mesmo os tradicionais aliados britânicos sinalizaram o seu apoio a São Petersburgo, na medida em que os interesses da Grã-Bretanha também eram afetados pelo ritmo da expansão norte-americana na China. Diante da persistente resistência das potências europeias, a Casa Branca chegou a considerar, como destaca LaFeber, a possibilidade de "abandonar a Open Door Policy e se juntar às outras potências coloniais" (LaFeber, 1989, p. 209), anexando diretamente uma parte do território chinês na condição de colônia dos Estados Unidos.

A tentação de abandonar a Open Door Policy na China não se concretizou. Hay alertou McKinley para os inúmeros riscos envolvidos em tal decisão. Embora gozassem de proeminência econômica, os Estados Unidos ainda não possuíam Forças Armadas suficientemente desenvolvidas para enfrentar os países europeus e o Japão na Ásia caso as antigas potências colonialistas se unissem contra Washington. Além disso, observou Hay, a mera anexação de uma parte do território chinês tiraria dos Estados Unidos as vantagens competitivas das quais usufruía em toda a China. E por fim, na visão do secretário de Estado, a opinião pública e a imprensa norte-americanas dificilmente apoiariam uma política externa expansionista que não estivesse, ao menos no campo da retórica e da ideologia, comprometida com a liberdade e com a autodeterminação dos povos.

Os argumentos de Hay acabaram convencendo McKinley de que a insistência na Open Door Policy era a estratégia que melhor representava os interesses dos Estados Unidos na China e no resto do mundo. E o 
melhor caminho para reafirmar essa política era precisamente aquele seguido entre 1899 e 1900, período em que os Estados Unidos se esforçaram para manter as potências europeias e o Japão desalinhados entre eles, frequentemente incitando conflitos entre as potências colonialistas. Ao mesmo tempo, os britânicos e os franceses, parceiros "naturais" dos Estados Unidos, deveriam receber garantias de que teriam os seus interesses respeitados, desde que isso não implicasse qualquer limite à expansão do capital norte-americano.

Assim, os Estados Unidos lidaram com os conflitos que emergiam na Ásia, durante boa parte da primeira metade do século XX, acomodando tensões pontuais; estimulando rivalidades entre o Japão, a Rússia, a Grã-Bretanha, a França e a Alemanha; consolidando o seu poder sobre as Filipinas, que se transformou na principal base militar norte-americana na Ásia; e assegurando que nenhuma barreira ficasse no caminho do capital norte-americano em sua expansão pelas prósperas fronteiras asiáticas. Aos Estados Unidos não interessava uma colônia chinesa ou parte dos mercados mundiais. As portas do mundo deveriam estar incondicionalmente abertas onde quer que fosse vislumbrada uma oportunidade para a expansão da fronteira econômica dos Estados Unidos.

\section{Os desafios para manter as portas da China abertas aos Estados Unidos: Theodore Roosevelt e a conflituosa aliança com o Japão}

A política externa da Casa Branca teve de lidar, nos primeiros anos do século XX, com um desafio central à Open Door Policy: a defesa dos interesses econômicos e políticos dos Estados Unidos na Ásia, num contexto em que as potências europeias, a Rússia e o Japão disputavam ferrenhamente os mercados chineses que ainda não haviam sido absorvidos pelo voraz expansionismo das empresas norte-americanas.

Apesar das disputas pelo controle dos mercados asiáticos, ao final de 1900, a crise na China tinha, aparentemente, sido vencida pelos Estados Unidos: os Boxers foram controlados e as empresas norte-americanas que atuavam no mercado chinês voltaram a ter as garantias necessárias para o bom desempenho dos seus negócios. McKinley pôde, então, se dedicar à corrida presidencial nos Estados Unidos, sem, no entanto, 
esquecer as questões internacionais. Na medida em que a política externa se convertera no principal tema da campanha presidencial, McKinley enfrentava, desde 1898, um forte movimento de oposição política, que abraçara a bandeira do "anti-imperialismo" para condenar a política conduzida pela Casa Branca na China e nas Filipinas (LaFeber, 1989, p. 211).

Apesar da ferrenha oposição doméstica, McKinley não cedeu à pressão dos "anti-imperialistas" e indicou Theodore Roosevelt como vice-presidente em sua campanha pela reeleição. De acordo com LaFeber, nenhum outro republicano encarnava melhor a defesa da Open Door Policy do que Roosevelt. Governador de Nova York em 1900, Roosevelt aceitou com relutância a indicação para a Vice-Presidência, mas engajou-se com afinco na corrida presidencial. De fato, boa parte do contra-ataque republicano durante a campanha de 1900 foi encabeçada por Roosevelt, que correu o país rebatendo as acusações do grupo "anti-imperialista", liderado pelo candidato democrata à Presidência, William J. Bryan.

Theodore Roosevelt defendia que, tendo em vista a incorporação das Filipinas ao território norte-americano, a postura anti-imperialista dos democratas em relação ao poder dos Estados Unidos naquela região significava, na prática, o desrespeito à integridade territorial estadunidense (um argumento muito convincente para a sociedade da época). Do mesmo modo, Roosevelt argumentava que a extrapolação dos argumentos "anti-imperialistas" facilmente levaria à conclusão de que, assim como as Filipinas deveriam ser deixadas aos filipinos, os Estados Unidos também deveriam abandonar o Arizona aos Apaches. Roosevelt também evocava argumentos sectários e racistas, afirmando que, numa eventual vitória de Bryan, os democratas poderiam estender a Declaração de Independência aos negros da região Sul dos Estados Unidos. Para Roosevelt, em síntese, os argumentos anti-imperialistas eram falaciosos, uma vez que as baionetas eram necessárias porque "os bárbaros só se renderão à força" (LaFeber, 1989, p. 212).

A estratégia eleitoral, agressiva e permeada por intolerância, seguida por McKinley e Roosevelt surtiu efeitos.Alguns meses antes das eleições, os democratas foram forçados a abandonar os argumentos anti-imperialistas, na medida em que os candidatos republicanos conseguiram traduzir a oposição à Open Door Policy numa expressão de antiamericanismo. 
Alternativamente, o candidato democrata à Casa Branca passou a criticar a política econômica republicana, o que enterrou definitivamente a sua campanha: na esfera econômica, os republicanos gozavam de inquestionável prestígio. Na década de 1890, os Estados Unidos emergiram da depressão e adentraram numa fase de rápido crescimento e vasta prosperidade, o que assegurava à McKinley os argumentos necessários para fazer frente a qualquer outra crítica à sua política econômica.

A reeleição de McKinley em 1900 foi celebrada mesmo por aqueles que, eventualmente, tinham nutrido simpatia pelo movimento anti-imperialista, mas que reconheciam o presidente por ter conduzido os Estados Unidos ao seleto grupo das grandes potências mundiais. McKinley soube explorar o momento e, logo após a eleição, continuou aclamando os beneficios da Open Door Policy. Contudo, pouco tempo após a reeleição, em setembro de 1901, numa exposição na cidade de Búfalo, Nova York, McKinley foi assassinado e Theodore Roosevelt assumiu a Presidência dos Estados Unidos.

LaFeber observa que Roosevelt, aclamado por muitos depois dele como o "espírito da América moderna", era um homem complexo. Educado em Nova York por tutores tradicionais, historiador graduado em Harvard e um amante das artes, o presidente era, antes de tudo, um membro da elite estadunidense, afinado com os seus interesses e ciente de suas preocupações. Porém, Roosevelt também era, nos termos de LaFeber, "um cowboy de Dakota do Sul” (LaFeber, 1989, p. 219), onde residira após a morte de sua esposa, o que lhe conferia um atributo muito especial: a capacidade de se comunicar com as massas, ao mesmo tempo em que transitava com desenvoltura pela elite norte-americana.

LaFeber observa outro traço marcante da personalidade de Roosevelt: a sua agressividade e o seu apego às armas. Daí o amor do presidente pela caça e também o seu apreço (nos livros e textos que publicou enquanto exercia o oficio de historiador) pela guerra como meio para defender os interesses dos Estados Unidos. Esses traços de sua formação e de sua personalidade são importantes, na interpretação proposta por LaFeber, para entender a forma como os Estados Unidos conduziram a Open Door Policy na primeira década do século XX, especialmente em suas relações com a Ásia.

Segundo LaFeber (1989, p. 235), Theodore Roosevelt acreditava fervorosamente que o futuro dos Estados Unidos dependia diretamente 
dos eventos na Ásia, o que justificava, portanto, a especial atenção na condução da política externa norte-americana com aquele continente. Roosevelt havia conduzido boa parte dos esforços dos Estados Unidos para conquistar as Filipinas e transformá-la numa base para a defesa dos interesses norte-americanos na Ásia, de modo que a defesa da Open Door, especialmente na China, tornou-se a prioridade de sua política externa. As diretrizes de política externa que orientavam o presidente eram compartilhadas por um de seus amigos mais próximos, Brooks Adams, para quem havia chegado o momento dos Estados Unidos "dominarem o mundo, como nenhuma nação o dominou na época recente" (Aaron, 1951, p. 268).

Brooks Adams, apontado por William Appleman Williams como um dos idealizadores da Open Door Policy, sustentava que a China era a "nova fronteira Oeste" dos Estados Unidos ${ }^{4}$. Conselheiro de Roosevelt nos assuntos exteriores, Adams recomendou que o presidente empenhasse todo o esforço necessário para consolidar o poder norte-americano sobre a China. O primeiro passo seria a construção do "mais barato, do mais eficiente sistema de transporte para levar as mercadorias [norte-americanas] para a Ásia” (LaFeber, 1989, p. 235). A Casa Branca respondeu aos conselhos de Adams com uma reforma legal que criou uma série de agências, controladas pelo Governo Federal, para regular as estradas de ferro e os portos dos norte-americanos, de modo a garantir uma base interna suficientemente forte para projetar os interesses dos Estados Unidos pela Ásia (LaFeber, 1989, p. 237).

Também sob a influência das ideias de Adams, Roosevelt buscou assegurar que as portas da China continuariam abertas aos interesses norte-americanos, conquistando o apoio do Japão, que sinalizava com o aceite das condições norte-americanas para resguardar os seus próprios interesses em relação aos mercados chineses. A aliança entre os Estados Unidos e o Japão, no começo do século XX, era, na interpretação proposta por LaFeber, o ponto central da política externa norte-americana na China: ao garantir o apoio da principal potência militar da Ásia, os Estados Unidos limitavam, ao mesmo tempo, as ambições japonesas e o expansionismo russo sobre a região (LaFeber, 1989, p. 237).

4 Ver Adams (2010). 
As tentativas da Rússia de controlar a Manchúria e a Coreia eram preocupações centrais para os Estados Unidos no começo do século XX. O secretário de Estado norte-americano, John Hay, acreditava que uma aliança entre Tóquio, Londres e Washington era o caminho mais interessante para isolar os russos e assegurar a contenção das ambições expansionistas do czar.

A aliança norte-americana com Tóquio rendeu o seu primeiro fruto em 1904, quando os japoneses lançaram um ataque surpresa que destruiu a maior parte da esquadra da Marinha russa no Pacífico. O apoio político de Washington aos japoneses foi imediato e estudos posteriores revelaram que banqueiros judeus sediados nos Estados Unidos, com uma memória vívida dos ataques antissemitas patrocinados pelo Império russo, proveram grandes empréstimos a Tóquio para bancar o esforço de guerra (LaFeber, 1989, p. 237). Além do claro sucesso das relações políticas entre os Estados Unidos e o Japão, a ofensiva militar contra a Rússia, em 1904, também estreitou os laços econômicos entre os dois países, criando uma articulada relação entre o capital financeiro nova-iorquino e o Estado japonês.

O sucesso da política externa norte-americana conduzida por Roosevelt era quase inquestionável. Quase, pois um dos críticos mais perspicazes da Open Door era, precisamente, Henry Adams, irmão de Brooks Adams. Numa carta particular enviada em 1904, Henry Adams manifestava a sua preocupação com a Open Door e as suas possíveis consequências para a relação entre os Estados Unidos e a Rússia:

Todos estão interessados, e excitados, e todos são contra a Rússia, quase que num grau perigoso. [...] estou meio louco com o medo de que a Rússia está navegando em direção a outra Revolução Francesa, que pode perturbar toda a Europa e também a nós [os EUA]. Um desastre sério com a Rússia pode arrebentar com toda a civilização. (Adams, 1938, p. 419)

Em 1905, a preocupação de Henry Adams começou a tomar forma. Uma revolução estourou na Rússia e, embora o czar tenha controlado os insurgentes, outros monarcas europeus passaram também a compartilhar a preocupação de Adams com o futuro do Império russo. Como consequência, as potências europeias se voltaram para os Estados Unidos, na tentativa de obter uma intermediação entre os russos e os japoneses 
que ao menos estabilizasse as tensões que rondavam a Europa e a Ásia. Roosevelt aceitou o desafio e convidou representantes dos dois governos para um encontro em New Hampshire, em 1905. LaFeber observa que, embora os interesses comerciais e políticos na China fossem o principal tema do encontro, nenhum representante de Pequim estava presente. No mesmo ano, após outras rodadas de negociação, a Rússia e o Japão finalmente assinaram um acordo de paz.

Ambas as nações concordaram em se retirar da Manchúria e a respeitar a integridade [territorial] da China (honrando, portanto, a Open Door). Mas o Japão emergiu [do acordo de paz] com controle sobre a Coreia, sobre portos chineses estratégicos antes controlados pela Rússia, sobre a principal ferrovia do Sul da Manchúria, e sobre a parte Sul da ilha de Sakhalin, antes reclamada pelo czar. No mês seguinte [ao acordo de paz], o Japão forçou a Coreia a se tornar um protetorado japonês. O Japão se manteria no controle [da Coreia] até 1945. (LaFeber, 1989, p. 238)

$\mathrm{Na}$ visão de LaFeber, o acordo de paz selado entre russos e japoneses estava, de fato, centrado nos interesses da Open Door Policy sustentada pelos Estados Unidos. Roosevelt esforçou-se, por todos os meios, para limitar ao máximo a presença russa na Ásia em geral e na China em particular. Nesse sentido, o reconhecimento da polêmica ingerência japonesa sobre a Coreia, observa LaFeber, foi uma troca de favores entre Washington e Tóquio: os norte-americanos respeitavam o domínio japonês sobre o território coreano e, em troca, o Japão não interferiria nas Filipinas (LaFeber, 1989, p. 238).

O sucesso do acordo de paz entre a Rússia e o Japão deve, contudo, ser relativizado à luz das consequências para a própria política externa dos Estados Unidos na China. Os chineses continuavam a nutrir os mesmos sentimentos de revolta contra a ingerência estrangeira e, em especial, contra o poder dos Estados Unidos. As restrições à imigração chinesa para os Estados Unidos e os laços entre Washington e Tóquio também desagradavam a Pequim, de modo que, em 1905, a China promoveu um amplo e eficiente boicote às mercadorias norte-americanas, que só foi interrompido quando grandes corporações dos Estados Unidos pressionaram a Casa Branca por uma solução. A mensagem era clara: a Open Door Policy gestava, entre os chineses, um profundo 
ressentimento contra os Estados Unidos e o Japão, num prenúncio de grandes problemas.

A aliança com o Japão provou-se ainda mais conflituosa e problemática. O controle sobre a Coreia permitiu que o Japão fechasse o país aos interesses dos Estados Unidos, ao mesmo tempo em que Tóquio aproveitou a vitória contra os russos para expandir as suas relações comerciais na Manchúria, ameaçando, assim, os interesses expansionistas norte-americanos na Ásia.Ao mesmo tempo, dentro dos Estados Unidos, aumentavam os protestos contra os imigrantes japoneses. Na Califórnia, onde o número de imigrantes japoneses havia saltado de 2 mil em 1890 para 24 mil em 1900, o grande fluxo migratório foi classificado de "ameaça japonesa" (LaFeber, 1989, p. 239). Sob protesto de Tóquio, Roosevelt sinalizou que aceitaria uma eventual lei proibindo a imigração japonesa para os Estados Unidos, a exemplo das restrições contra os chineses. Porém, num acordo diplomático incomum, o governo japonês anunciou, em 1907, a proibição da emigração de japoneses para os Estados Unidos.

LaFeber ressalta que, do atrito com os japoneses em 1907, Roosevelt tirou uma importante lição: os Estados Unidos haviam firmado laços com uma potência igualmente expansionista, cujos interesses se chocavam com a Open Door Policy. A resposta do presidente foi, entretanto, muito contundente: no mesmo ano, uma esquadra com 16 navios de guerra da Marinha dos Estados Unidos foi enviada para um "giro" pelo mundo, com uma parada especial na costa sino-japonesa. O Japão entendeu o recado enviado pela esquadra norte-americana, mas manteve a sua influência sobre a Coreia e os seus interesses na Manchúria.

Entre 1907 e 1908, outro foco de tensão entre o Japão e os Estados Unidos confirmou o aumento da animosidade entre os dois aliados. Sob a liderança do empresário Edward Henry Harriman, os Estados Unidos buscavam a construção de uma ferrovia na Manchúria, que competiria diretamente com a principal estrada de ferro da região controlada pelos japoneses. Num acordo celebrado em 1908 (Acordo de Root-Takahira), os Estados Unidos desistiram da ferrovia que já estava em construção e reconheceram a proeminência japonesa sobre o Sul da Manchúria. Em contrapartida, Tóquio reafirmou os princípios da Open Door e reconheceu a independência da China, tomando, todavia, o cuidado de não se comprometer com a integridade territorial chinesa. LaFeber conclui que Roosevelt - agraciado com o Nobel da Paz por intermediar o fim 
da Guerra Russo-Japonesa - compreendeu os limites da expansão norte-americana na Ásia e soube reconhecer a importância de uma aliança com a principal potência da região para assegurar os interesses norte-americanos. Como destaca o autor,

na realidade, Roosevelt abriu mão da Open Door na maior parte da Manchúria. Ele evitou, entretanto, uma guerra contra o Japão e alcançou um acordo frágil com a potência emergente da Ásia. Para um homem que amava tanto a guerra e a matança, ele demonstrou uma extraordinária sensibilidade para os limites do poder dos Estados Unidos. [...] Ao lidar com os índios e com os latino-americanos, T. R. de fato usou a força ao tratar com povos mais fracos. Na Ásia e na Europa, entretanto, ele sabia que os Estados Unidos não estavam em pé de igualdade. Ele, então, seguiu um conselho que aprendera nos bares da fronteira de Dakota do Norte: "Nunca saque a sua arma a menos que pretenda atirar”. (LaFeber, 1989, p. 240)

A grande questão, segundo LaFeber, era até que ponto os sucessores de Roosevelt na Casa Branca teriam a mesma sensibilidade para conduzir a expansão das fronteiras econômicas norte-americanas na Ásia e para lidar com o adensamento dos atritos com outras potências colonialistas interessadas na China. Ao final do governo Roosevelt, o aprofundamento das tensões com as potências colonialistas deixou claro que a condução da Open Door Policy na Ásia era um desafio cada vez maior para os Estados Unidos. Os governos de William Howard Taft (19091913) e de Woodrow Wilson (1913-1921), em especial, pagaram um alto preço para sustentar uma política externa expansionista, com uma retórica anticolonialista claramente subordinada aos interesses de uma nova potência imperial em ascensão.

\section{Considerações finais}

Ao analisar as transformações da política externa estadunidense, na virada do século XIX para o século XX, a corrente historiográfica revisionista concluiu que a incorporação da "frontier thesis" implicou, nos termos de Williams, a condução de uma política externa comprometida com o "anticolonialismo imperial": ao combater o colonialismo das potências europeias, os Estados Unidos defendiam, de fato, os seus pró- 
prios interesses expansionistas imperiais e sinalizavam a disposição de ir à guerra para sustentar a expansão de suas fronteiras econômicas pelo mundo. Assim o foi, na interpretação proposta por Williams, na Guerra Hispano-Americana de 1898, em que o conflito pela "libertação" das colônias espanholas estava primordialmente centrado no projeto de expansão das fronteiras econômicas norte-americanas por regiões estratégicas: em Cuba, pelas relações comerciais mantidas há tempos com os Estados Unidos; em Guam e nas Filipinas, pela proximidade com o desejado mercado asiático; e em Porto Rico, como reafirmação da Doutrina Monroe.

LaFeber partiu de uma interpretação muito semelhante à de Williams, identificando na política externa expansionista conduzida pelos Estados Unidos desde o século XIX a origem de diversos conflitos. Assim, a discussão sobre as ideias de LaFeber foi centrada em sua bem articulada interpretação sobre os conflitos engendrados pelos Estados Unidos com as potências colonialistas europeias, o Japão e a Rússia em torno da defesa da Open Door Policy na Ásia em geral e na China em particular.

Argumentei que, na interpretação de LaFeber, a Guerra Hispano-Americana de 1898 conferiu aos Estados Unidos uma oportunidade singular de projetar o poder norte-americano sobre a Ásia. A vitória sobre os espanhóis foi, nesse sentido, fundamental para a defesa da Open Door Policy porque conferiu a Washington o controle sobre pontos estratégicos na Ásia (Guam e, principalmente, as Filipinas), que forneceram uma base para a disputa com a Alemanha, a França, a Grã-Bretanha, a Rússia e o Japão pelo acesso aos mercados chineses.

Sublinhei que, a despeito do amplo sucesso econômico da Open Door Policy na Ásia, o grande dilema envolvido nessa política externa expansionista eram, como sustentado por LaFeber, os diversos conflitos alimentados entre os Estados Unidos, as tradicionais potências imperialistas e a própria China (onde cresciam os movimentos sociais de oposição à ingerência estrangeira).

Ao analisar a interpretação de LaFeber sobre os conflitos catalisados pela Open Door Policy, destaquei as tortuosas relações entre os Estados Unidos e o Japão. Ressaltei a crença do governo de Theodore Roosevelt na ideia de que o futuro dos Estados Unidos dependia diretamente dos eventos na Ásia. Baseado nas ideias de Brooks Adams (o mesmo idealizador da "frontier thesis", analisado por Williams), o presidente Roosevelt 
se esforçou para firmar uma aliança política e econômica com o Japão, garantindo, simultaneamente, o apoio da principal potência militar da Ásia e a limitação das ambições japonesas e russas na China. Dessa forma, demonstrei que, na interpretação de LaFeber, a aliança entre os Estados Unidos e o Japão foi um alicerce crucial da política externa norte-americana na Ásia. Uma atenção especial foi dedicada também à importância da aliança com os japoneses para isolar os russos e assegurar a contenção das ambições expansionistas do czar na Manchúria e na Coreia, aumentando, contudo, o desgaste das relações entre Washington e São Petersburgo.

A aliança entre Tóquio e Washington nas primeiras décadas do século XX foi também analisada, em linha com a interpretação proposta por LaFeber, em face dos conflitos decorrentes dessa aproximação.Assim, observei que, embora importante para a defesa dos interesses norte-americanos na China, a aliança com os japoneses também resultou numa série de problemas para a Casa Branca. Os Estados Unidos haviam firmado laços com uma potência também expansionista, cujos interesses se chocaram, por diversos momentos, com a Open Door Policy.

$\mathrm{O}$ artigo foi encerrado apontando os grandes desafios que continuaram no caminho dos Estados Unidos nas décadas posteriores ao governo de Theodore Roosevelt, no decurso de uma política externa orientada pelos princípios da Open Door Policy.

\section{Referências bibliográficas}

AARON, Daniel. Men of good hope.A story of American progressives. França: Ullan Press, 1951.

ADAMS, Brooks. The law of civilization and decay: an essay on history. New York: Kessinger Publishing, 2010 (1895).

ADAMS, Henry. Letters of Henry Adams, 1892-1918. Ed. Worthington Chauncey Ford. Boston, 1938.

COMBAT, Flávio Alves. A centralidade do pensamento de William Appleman Williams no debate historiográfico sobre a Guerra Fria. Esboços. Florianópolis, v. 23, n. 36, p. 404-428, fev. 2017.

GADDIS, J. L. The United States and the origins of the Cold War, 1941-1947. New York: Columbia University Press, 1972.

HAY, Jonh. Open Door Notes, 1899-1900. Disponível em <http://www.pinzler.com/ ushistory/opendoorsupp.html>. Acesso em 30/9/2012. 
KENNAN, George Frost. The sources of Soviet conduct. Foreign Affairs, July 1st. 1947.

LAFEBER, Walter. John Hay. In: Encyclopedia of American biography. Eds. John A. Garraty, Jerome L. Sternstein. New York, 1974.

LAFEBER, Walter. The American age. United States Foreign Policy at home and abroad since 1750. New York: Norton \& Company, 1989.

MUNHOZ, Sidnei J. Guerra Fria: um debate interpretativo. In:TEIXEIRA DA SILVA, Francisco Carlos. O século sombrio: uma história geral do século XX. Rio de Janeiro: Campus, 2004

SIRACUSA, Joseph M. New Left diplomatic histories and historians. The American revisionists. California: Regina Books, 1993.

SMITH, David M. The New Left and the Cold War. Review of: Empire and revolution: a radical interpretation of contemporary world history (David Horowitz). Denver Quarterly, n. 4, winter 1970.

SUGITA, Yoneyuki. The rise of an American principle in China: a reinterpretation of the first Open Door Notes toward China. In: JENSEN, R.; DAVIDANN, J. T.; SUGITA,Y. (eds.). Trans-Pacific relations: America, Europe, and Asia in the twentieth century. Greenwood: Praeger, 2003, p. 3-20.

WILLIAMS, William Appleman. The tragedy of American diplomacy. New York: Norton, 1988 (1959). 